\title{
Bladder Hemangioma
}

National Cancer Institute

\section{Source}

National Cancer Institute. Bladder Hemangioma. NCI Thesaurus. Code C159680.

A hemangioma that arises from the bladder. Most tumors occur in adults. 